Matematikai Közlemények

VI. kötet, 2018

doi:10.20312/dim.2018.02

\title{
A 120-cella és a 600-cella 3-dimenziós reprezentációiról
}

\author{
Talata István \\ Szent István Egyetem, \\ Ybl Miklós Építéstudományi Kar, Budapest, \\ és Dunaújvárosi Egyetem, Dunaújváros \\ talata.istvan@ybl.szie.hu
}

\begin{abstract}
ÖssZEFOGLALÓ. Bemutatjuk, hogyan lehet megjeleníteni a 120-cella laphálóját a 3-dimenziós euklideszi térnek olyan parkettázásaként, melynek minden eleme konvex poliéder vagy annak komplementere, és a parkettázás cellarendszere a szabályos dodekaéder szimmetriáival rendelkezik. Konstrukciókat mutatunk a 600cella élgráfjának dodekaéderes szimmetriájú 3-dimenziós reprezentációira is. Végezetül összegezzük a szerzőnek a témakörrel kapcsolatos oktatási tapasztalatait.
\end{abstract}

\begin{abstract}
We demonstrate how we can represent the face lattice of the 120-cell as a tiling of the 3-dimensional Euclidean space in which every cell is a convex polyhedron or its complement, and the cell system of the tiling possesses the symmetries of a regular dodecahedron. We construct 3D representations of the edge graph of the 600-cell with dodecahedral symmetry as well. Finally, we sum up the educational experiences of the author in this subject.
\end{abstract}

\section{Bevezetés}

Két probléma motiválta a szerzőt ebben a munkában. Egyrészt, mivel a 120-cella és a 600-cella szerkezetét leginkább csak bonyolult ábrák láttatják, ezért jó lenne olyan ábrázolásuk, amely világosan bemutatja a szerkezetüket, mindenféle hosszadalmas leírás nélkül! Másrészt, a 120-cella laphálójának poliéderekből álló térbeli parkettázással való modellezését érdemes lehet-e a felsőoktatásban térgeometriai feladatként feladni?

Idézzük fel a konvex politópok alaptulajdonságait! A $d$-dimenziós euklideszi térben $(d \geq 0) k$-dimenziós konvex politópnak $(0 \leq k \leq d)$ hívunk egy konvex halmazt, ha az előáll, mint véges sok, affin hipersík által határolt zárt féltér metszete, amelynek affin burka egy $k$-dimenziós affin altér (amely persze tekinthető egy $k$-dimenziós euklideszi térnek is). Egy $d$-dimenziós konvex politópnak egy olyan affin hipersíkkal (támaszhipersíkkal) vett metszetét, amely nem tartalmazza a politóp belső pontjait (és így a politóp a hipersík által határolt egyik zárt féltérben helyezkedik el), a poliéder egy lapjának nevezzük (plusz még a politópot magát a politóp $d$-dimenziós lapjának is tekintjük). Egy $d$-dimenziós konvex politópnak a valódi lapjai (azaz a legfeljebb $(d-1)$-dimenziós lapjai) nála kisebb dimenziós konvex politópok, határa pedig hiperlapjainak (azaz $(d-1)$-dimenziós lapjainak) uniója. Egy politóp lehet korlátos vagy nem korlátos. A korlátos konvex politópok megkaphatók, mint véges sok pont (a csúcsaik, azaz a 0-dimenziós lapjaik) konvex burka. A 2-dimenziós korlátos konvex politópokat konvex sokszögnek, a 3-dimenziós konvex politópokat konvex poliédernek hívjuk.

KULCSSZAVAK. Szabályos test, konvex poliéder, parkettázás, szimmetria, geometria oktatás. KEYWORDS. Regular solid, convex polyhedron, tiling, symmetry, geometry education. 
Egy $d$-dimenziós konvex politóp lapjainak összessége a tartalmazás relációra nézve részben rendezett halmaz, amely egy algebrai háló - ezt a politóp laphálójának hívjuk. A laphálóval ekvivalens hálót kapunk a tartalmazás relációra nézve, ha a különböző dimenziós lapok helyett azok csúcshalmazait vesszük a háló elemeinek.

Egy $d$-dimenziós konvex politóp 0-dimenziós lapjait csúcsoknak, 1-dimenziós lapjait éleknek, 3-dimenziós lapjait celláknak, $(d-1)$-dimenziós lapjait hiperlapoknak hívjuk, ill. a 3-dimenziós konvex poliéderek 2-dimenziós lapjait röviden lapoknak is hívhatjuk. A $k$-dimenziós lapokra a $k \mathrm{D}$ lap elnevezést is használhatjuk. A $k$-dimenziós politópokra a $k \mathrm{D}$ politóp, vagy $k$-politóp elnevezés is használható. A laphálónak a tartalmazás relációra vett maximális láncai $(d+1)$ elemủek, 0 -dimenziós laptól $d$-dimenziós lapig bezárólag minden dimenziós lapból tartalmaznak egyet, az előző elem a rákövetkező elem részhalmaza.

A $d$-dimenziós euklideszi térben szabályos testnek nevezünk egy $d$-dimenziós konvex politópot, ha az korlátos, minden hiperlapja egy szabályos $(d-1)$-dimenziós test, hiperlapjai egybevágók, minden csúcsalakzata egy szabályos $(d-1)$-dimenziós test, és csúcsalakzatai egybevágók. (Szabályos test csúcsalakzatán az egy csúcsból kiinduló éleken a csúcstól adott távolságra levő pontok konvex burkát értjük, amikor az a távolság az élek hosszánál kisebb.) Szabályos testek szimmetriacsoportja tranzitívan hat a lapjainak dimenzió szerint növekvő maximális láncain, azaz bármely két ilyen lánchoz létezik olyan egybevágósága a $d$-dimenziós térnek, melyik az egyik láncot a másikba viszi, és így a testet is önmagára képezi le (tehát ez a testnek egy szimmetriája). Ez utóbbi tulajdonság ekvivalens a szabályos testek definíciójával.

Az euklideszi terekben a szabályos testek (hasonlóság erejéig) a következők:

- síkban a szabályos konvex sokszögek (végtelen sok ilyen van),

- három dimenzióban a szabályos tetraéder, oktaéder, kocka, ikozaéder, és a dodekaéder (5 test),

- négy dimenzióban a szabályos 4-szimplex (5-cella), a 4D kocka (8-cella), a 4D kereszt-politóp (16-cella), a 24-cella, a 120-cella, és a 600-cella (6 test),

- $d$-dimenziós terekben $(d \geq 5$ ) csak a szabályos $d$-szimplex, a $d$-dimenziós hiperkocka és a $d$-dimenziós keresztpolitóp a szabályos testek (3 test).

A szabályos testek minden lapja (akárhány dimenziós lapja, pl. hiperlapja, 2D lapja) szabályos test (persze egy kisebb dimenziós térbeli szabályos test). Ha egy 4-dimenziós szabályos testet $n$-cellának neveznek valamely $n$ számra, akkor ez azt jelenti, hogy $n$ darab hiperlapja (azaz $n$ darab 3-dimenziós lapja) van.

A 4-dimenziós szabályos politópokról pár jellemző:

- a szabályos 4-szimplex (5-cella) cellái tetraéderek, egy csúcsban 4 cella találkozik, egy élre 3 cella illeszkedik (azaz egy élét 3 cella tartalmazza),

- a 4D kocka (8-cella) cellái kockák, egy csúcsban 4 cella találkozik, egy élre 3 cella illeszkedik,

- a 4D keresztpolitóp (16-cella) cellái tetraéderek, egy csúcsban 8 cella találkozik, egy élre 4 cella illeszkedik,

- a 24-cella cellái oktaéderek, egy csúcsban 6 cella találkozik, egy élre 3 cella illeszkedik,

- a 120-cella cellái dodekaéderek, egy csúcsban 4 cella találkozik, egy élre 3 cella illeszkedik,

- a 600-cella cellái tetraéderek, egy csúcsban 20 cella találkozik, egy élre 5 cella illeszkedik.

Megjegyzendö, hogy 4D politópok esetében bármely 2D lapra 2 cella illeszkedik (azaz egy 2D lapot 2 cella tartalmaz). 
Mindegyik szabályos testnek van egy duális politópja (pl. a hiperlapközéppontok konvex burka), az is szabályos test. Duális politóp duálisa önmaga (hasonlóság erejéig), így a dualitás szimmetrikus reláció. A szabályos tetraéder duálisa szabályos tetraéder, a kocka duálisa oktaéder. Dodekaéder duálisa ikozaéder. A szabályos 4-szimplex duálisa önmaga, a 4D kocka duálisa 4D keresztpolitóp. A 24-cella duálisa önmaga. A 120-cella duálisa 600-cella. Szabályos $d$-szimplex duálisa önmaga, a $d$-dimenziós hiperkocka duálisa $d$-dimenziós keresztpolitóp.

A következő fejezetben a 120-cella szerkezetét írjuk le részletesebben.

\section{A 120-cella}

A 4-dimenziós szabályos politópok laphálóit már azok a lokális tulajdonságok is egyértelmüen meghatározzák, hogy melyik poliéder laphálójával ekvivalensek a celláinak laphálói, mennyi cellája találkozik egy csúcsban és mennyi cellája illeszkedik egy élre. Azonban ezek csak lokális tulajdonságok, azaz az egy csúcsra illeszkedö, vagy legfeljebb az egy adott cellával legalább egy közös pontot tartalmazó cellák elrendezését lehet egyszerüen meghatározni az előbb említett összefüggésekből, az egész lapháló szerkezetét nem írják le.

Főleg a sok cellából álló szabályos 4D politópok esetében (120-cella, 600-cella) elég komplex a lapháló struktúrája - ezekben az esetekben nem is ismert olyan ábrázolása a laphálónak, vagy akárcsak az élgráfnak (a csúcsokat és az éleket tartalmazó gráfnak), amely egy ábrában, és áttekinthető módon ábrázolja az illeszkedéseket.

A fejezet további részében leírjuk a 120-cella szerkezetének fontosabb jellemzőit.

A 120-cella alaptulajdonságai: 120 szabályos dodekaédercella alkotja, minden csúcsban 4 dodekaéder találkozik, minden élre 3 dodekaéder illeszkedik. 600 csúcsa, 1200 éle és 720 darab 2-dimenziós lapja van.

A 120-cella celláinak családját csoportokba, „rétegekbe” oszthatjuk úgy, hogy egy tetszőleges celláját kiválasztjuk, és a cellák szimmetriaközéppontjainak a távolságait tekintjük a kiválasztott cella szimmetriaközéppontjától. Ekkor az azonos távolságra levő cellaközéppontokhoz tartozó cellák alkotnak egy réteget. A távolságok szerinti növekedö sorrendben indexeljük az egyes rétegeket. 9 réteg adódik.

Egy réteg cellaközéppontjai egy 3-dimenziós konvex poliéder csúcsaira illeszkednek (ezek a 3D poliéderek egymással párhuzamos affin hipersíkokban helyezkedek el, melyek a 120-cellának egy szimmetriatengelyére merőlegesek), kivéve az 1. és 9. réteget, amelyek 1-1 cellából állnak. A rétegek a következőképp jellemezhetők, a cellaközéppontjaik konvex burkával (ld. [1], [3]):

- 1. réteg (1 cella): a kiválasztott cella,

- 2. réteg (12 cella): ikozaéderes elrendezés,

- 3. réteg (20 cella): dodekaéderes elrendezés,

- 4. réteg (12 cella): ikozaéderes elrendezés,

- 5. réteg (30 cella): ikozidodekaéderes elrendezés,

- 6. réteg (12 cella): ikozaéderes elrendezés,

- 7. réteg (20 cella): dodekaéderes elrendezés,

- 8. réteg (12 cella): ikozaéderes elrendezés,

- 9. réteg (1 cella): a kiválasztott cellával átellenes cella.

Tovább pontosítható a rétegek cellaközéppontjainak az elhelyezkedése a következőképp. Jelölje $D_{0}$ a kiválaszott dodekaédercellát, $I_{0}$ jelölje a $D_{0}$ cella lapközéppontjai által meghatározott ikozaédert, $F_{0}$ pedig jelölje a $D_{0}$ cella élfelezőpontjai által meghatározott ikozidodekaédert (egy dodekaéder élfelezőpontjai pontosan egy ikozidodekaéder csúcsait 
adják ki). Ekkor $D_{0}, I_{0}$, és $F_{0}$ egyaránt a 120-cellának ugyanabban a támaszhipersíkjában vannak a 4-dimenziós euklideszi térben. Legyen $f$ az az egyenes, amely merőleges a támaszhipersíkra és átmegy $D_{0}$ szimmetriaközéppontján.

Ekkor a 2., 4., 6. és 8. rétegek mindegyikében a 12 cellaközéppont konvex burka egy olyan ikozaéder, amely középpontosan hasonló képe az $I_{0}$, ikozaédernek, az $f$ egyenes egy megfelelö pontját hasonlósági középpontnak választva.

A 3. és 7. rétegek mindegyikében a 20 cellaközéppont konvex burka egy olyan dodekaéder, amely középpontosan hasonló képe a $D_{0}$ dodekaédernek, az $f$ egyenes egy megfelelő pontját hasonlósági középpontnak választva.

$\mathrm{Az}$ 5. rétegben a 30 cellaközéppont konvex burka pedig egy olyan ikozidodekaéder, amely középpontosan hasonló képe az $F_{0}$ ikozidodekaédernek, az $f$ egyenes egy megfelelő pontját hasonlósági középpontnak választva.

Ha a 120-cellának az élgráfját síkban ábrázoljuk úgy, hogy a csúcsokat valamilyen módon (de általános helyzetben) elhelyezzük a síkon, és az éleket csúcspárokat összekötő egyenesszakaszokként ábrázoljuk, akkor a nagyszámú csúcs és él (600 csúcs, 1200 él) miatt eléggé áttekinthetetlen ábrát kapunk, még ha a csúcsokat szimmetrikus módon helyezzük is el, ld. [1]. (Általános helyzetü síkgráfon azt értjük, hogy nem esik egybe két csúcs, és nincs harmadik csúcs két, éllel összekötött csúcs összekötő szakaszán.) A 120-cella egyes ötszöglapjainak az élei olykor meghatározhatók, de a cellák élvázának az alakja általában eléggé átláthatatlan. A duális 600-cellánál (120 csúcs, 720 él) is hasonló a helyzet, nem lehet az élgráfját a síkban úgy ábrázolni, hogy a cellarendszer szerkezetét jól szemléltesse, ld. [2].

A dualitás miatt a 600-cella jellemzését nem szükséges részleteznünk, mert a 120-cella fentebb említett tulajdonságai könnyen átfogalmazhatók a 600-cella tulajdonságaira. A 600cella számunkra legfontosabb tulajdonságait azért a 4. fejezet elején összefoglaljuk.

\section{A 120-cella 3D reprezentációi}

A 3-dimenziós térben olyan, konvex poliéderekből vagy azok komplementereiből álló parkettázást szeretnénk előállítani, amelynek a laphálója ekvivalens a 120-cella laphálójával. Megjegyezzük, hogy parkettázáson olyan konvex poliéderekböl vagy komplementereikből álló fedését értjük a 3D térnek, amelyben a celláknak páronként nincs közös belső pontjuk, és bármely két poliéder metszete azok egy közös, valahány dimenziós lapja, vagy az üres halmaz. Parkettázás laphálóján pedig a parkettázás elemei és azok lapjai által meghatározott algebrai háló tértjük a tartalmazás relációra nézve. Előnyös minél több szimmetriával rendelkező cellarendszert tekintenünk, hogy minél kevesebb különböző alakú cella legyen a parkettázás cellarendszerében, ez az ábrázolás könnyebb áttekinthetőségét is segíti.

Ha a 120-cellát párhuzamos vetítéssel képezzük le egy 3-dimenziós affin alterére, akkor a 120-cella vetületét a celláinak a vetületei kétszeresen fedik: a cellái feloszthatók látható és nem látható cellákra (némely, a vetítősugárral párhuzamos cella képe elfajuló - azaz 2-dimenziós - lehet). Ezért párhuzamos vetítéssel nem kapunk a 120-cella laphálójából a 3-dimenziós tér konvex poliédereiből álló parkettázást, de azért ilyenkor is kapunk a lapháló egyik felét ábrázoló cellarendszert (ld. [3]), valamint hasonlón, a duális 600 cella-esetén is kapunk a lapháló egyik felét ábrázoló cellarendszert (ld. [4]).

A 120-cella centrális vetülete esetén, ha a vetítés az egyik cella által kifeszített 3-dimenziós hipersíkra történik, és a vetítés centruma elég közel van a cellának egy belső pontjához, akkor az összes többi cella vetülete abba a cellába esik bele. A vetítéskor fixen maradt cellára mondhatjuk, hogy annak képe legyen a cella 3-dimenziós hipersíkjának a külseje, ekkor a 120-cella laphálójával ekvivalens laphálójú, a teret parkettázó cellarendszert kapunk. Egyszerübben átlátható struktúrát kapunk dodekaéderes szimmetriájú centrális 
vetület esetén - ehhez szükséges, hogy a vetítés centruma a szabályos dodekaédercella középpontján átmenő, a dodekaédercellára meröleges egyenesen legyen rajta, így ekkor egyetlen paramétertől függ a vetület alakja. A sok cella miatt lesznek olyan cellák, melynek vetülete már nagyon kicsi a legkülső dodekaédercellához képest, ezért a vetületen a 120-cella egészének a szerkezete nem átlátható.

Sztereografikus projekcióval is ábrázolható a 120-cella: először a körülírt gömbjének a felszínére vetítjük a gömbközéppontból a celláit, majd egy gömbfelületi pontból (egy gömbi cella relatív belső pontjából) centrális vetítéssel az átellenes pont gömbi támaszhipersíkjára vetítjük a gömbi cellákat. Ekkor az egyik cella képe nem korlátos tartomány, a cellák vetületei kiadják az egész síkot, de sajnos a cellák képei nem poliéderek, hanem másodrendủ felületdarabok által határolt, olykor nem konvex testek.

A következökben olyan 3D cellarendszereket tekintünk, amelyek általánosítják azt az esetet, amikor dodekaéderes szimmetriával rendelkező centrális vetítést alkalmazunk a 120cellára, és ebből kapjuk a 3-dimenziós térnek egy parkettázását. Ezért a 3-dimenziós euklideszi térnek olyan parkettázásait vizsgáljuk, melyben minden cella egy, a szabályos dodekaéder laphálójával ekvivalens laphálójú konvex poliéder vagy annak komplementere, mindegyik csúcsban 4 cella találkozik és mindegyik élre 3 cella illeszkedik.

Ekkor a cellarendszer laphálója ekvivalens a 120-cella laphálójával, a cellarendszer szimmetriaközéppontját (jelöljük ez $O$-val) tartalmazó cellához (továbbiakban: központi cellához, a 2. fejezet $D_{0}$ jelölését használva rá) viszonyítva a cellákat, 9 rétegre bomlik fel a 3D cellarendszer, aszerint, hogy a celláknak megfeleltethetö 120-cellabeli hiperlap melyik rétegbe tartozik a központi cella hiperlapjához viszonyítva. A szimmetria miatt az egyes rétegekben a cellák egymással egybevágók.

A 2-8. réteg cellái olyan szimmetriákkal rendelkeznek, melyek egy dodekaédert fixen hagynak, és melyek ezen felül a dodekaéder egy lapját, vagy csúcsát, ill. élét is fixen hagyják. Tehát ezek a szimmetriák egy síkbeli alakzatot önmagába visznek, és a sík féltereit fixen hagyják, a következőképp:

- az 1. réteg egy szabályos dodekaéder,

- a 2., 4., 6., és 8. réteg cellái egy szabályos ötszög szimmetriáival rendelkeznek,

- a 3. és 7. réteg cellái egy szabályos háromszög szimmetriáival rendelkeznek,

- az 5. réteg cellái egy síkba ágyazott szakasz szimmetriáival (tehát pl. egy nem egyenlő oldalú téglalap szimmetriáival) rendelkeznek,

- a 9. réteg egy szabályos dodekaéder külseje.

Az ötszöges, háromszöges és téglalap szimmetriájú, dodekaéderrel ekvivalens laphálójú konvex poliéderek alakját (egybevágóság erejéig) befolyásoló független paraméterek számát megkapjuk, ha egy ilyen poliéder lapsíkjainak a szimmetriatengellyel bezárt szögeit, valamint ezen síkoknak a tengely egyik végpontjától vett távolságait tekintjük, és az egymástól független, nem konstans szögek, ill. távolságok maximális számát vesszük. (Szimmetriatengelyen azt a szakaszt értjük, amely a poliéder olyan szimmetriáinak a fixpontjaiból áll, melyek az adott síkidom -szabályos ötszög, szabályos háromszög, téglalapsíkjának a féltereit fixen hagyják.) Így adódik, hogy ötszöges szimmetriájú poliéder esetében 5 , háromszöges szimmetriájú poliéder esetében 7, téglalap szimmetriájú poliéder esetében 9 független paramétertől függ a cella alakja (csak a szimmetriafeltételt és a dodekaéderrel ekvivalens laphálót megkövetelve a konvex poliédertől - így azt, hogy ez a poliéder egy térbeli parkettázás egyik rétegének az eleme legyen, még nem vettük figyelembe).

A cellaparkettázás feltétele az egyes cellák konstrukcióinál a fentebbi szabadsági fokokat csökkenti. Ha ugyanis az 1. réteg $D_{0}$ szabályos dodekaéderét fixnek tekintjük, és a 2-8. rétegek poliédereit egymás után, a rétegek növekvő indexei alapján készítjük el, akkor az egyes rétegek celláinak a konstrukcióikor figyelembe kell venni a korábban elkészített 
rétegekkel közös lapokat, és hogy az egyes rétegeken belül a cellák sokszor közös lapokkal rendelkeznek. Így a cellaparkettázásra összesen 13 szabad paraméter adódik úgy, hogy a 2., 3. és 5. rétegnek 3 szabadsági foka van, a 4., 6., 7. és 8. rétegnek 1 szabadsági foka van. Persze a síklapok tengellyel bezárt szögei és tengely végpontjától vett távolságai helyett más paraméterek is használhatók, pl. a cellák élhosszai, oldallapjainak szögei közül a megfelelően kiválasztott mennyiségek Attól, hogy egy mennyiség szabad paraméter, még vannak rá korlátozó feltételek, és a többi paraméter értékétől is függ, hogy milyen intervallumon vagy intervallumokon választható meg úgy az értéke, hogy a kívánt tulajdonságú konvex poliédercellát kapjuk.

Amennyiben az ötszöges szimmetriájú cellákat, azaz a 2., 4., 6. és 8. rétegek poliédereit készítjük el először, azokhoz is 13 szabad paraméter rendelhetö, így ekkor a 3., 5. és 7. rétegek poliéderei már egyértelmüen adottak. A 2., 4., 6. és 8. rétegek összes cellája (48 darab) lefog a 120-cella 600 csúcsa közül 560-at, a maradék 40 csúcs közül 20 darab a 3. és 5. rétegek celláira, 20 darab pedig az 5. és 7. rétegek celláira illeszkedik. Az 1. ábrán láthatók az 1-8. réteg poliédercellái - a szabad paraméterek variálásával persze másféle alakú cellák is kaphatók. A 2. ábrán mutatjuk be a modellezési fázisokat, amikor az egyes rétegeket egymás után, indexeik szerint növekvő sorrendben adjuk hozzá a cellarendszerhez (az utolsó fázisban a 7. és 8. réteget egyszerre adtuk hozzá a cellarendszerhez, mert a 8. réteg áttetszősége miatt a 7. réteg is jól látszik ilyenkor).

Egy geometriai feltétel is adható a cellákra: ha a 2., 4., 6. és 8. rétegek ötszöges szimmetriájú poliédereit elkészítjük úgy, hogy közös lapjaik legyenek a 2. és 4., a 4. és 6 ., valamint a 6 . és 8 . rétegek poliédereinek, akkor azok egy olyan végtelen gúlában kell, hogy elhelyezkedjenek, melynek csúcsa a dodekaéderes szimmetria $O$ középpontja, és a gúlát az 1 . réteg $D_{0}$ szabályos dodekaéderének az egyik ötszöglapja feszíti ki. A 2. és 8. réteg poliédereinek is vannak lapjaik (5-5 darab) a végtelen gúla határán, így lesz a $D_{0}$ központi cella éleinél, valamint a 9. réteg dodekaéder éleinél a cellarendszer parkettázás (azaz így lesz ott hézagmentes a cellaelrendezés).

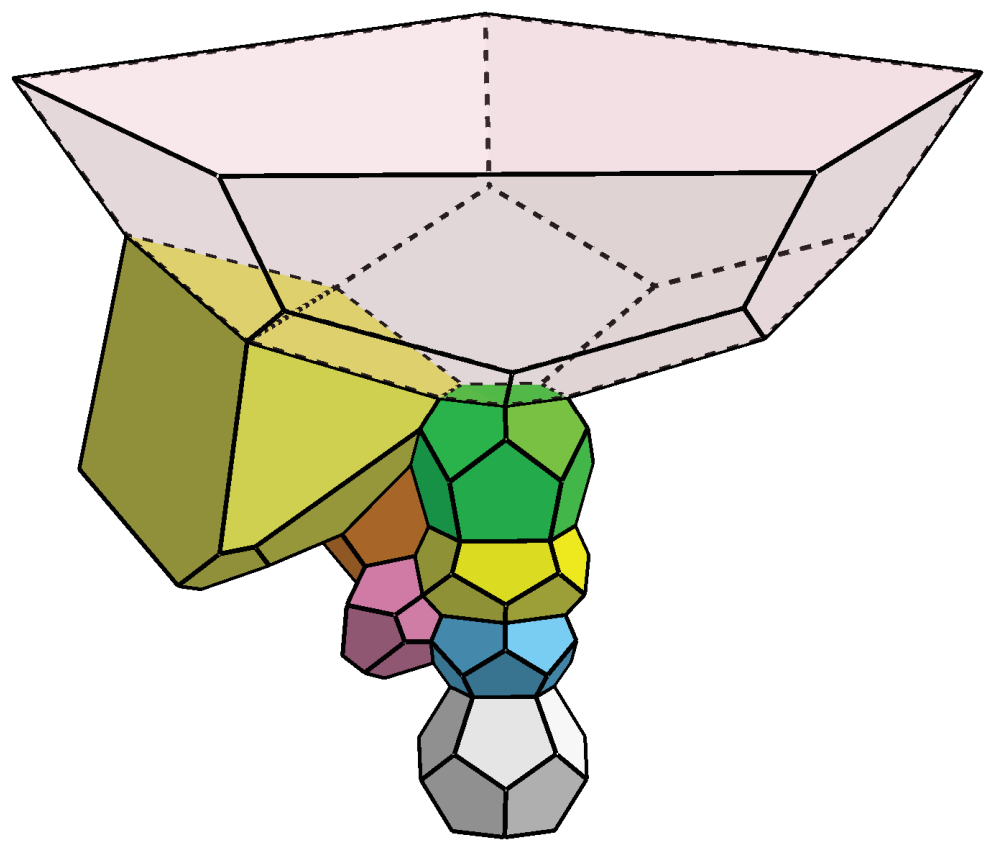

1. ábra. Az 1-8. réteg konvex poliéderei a 120-cella dodekaéderes szimmetriájú 3D reprezentációjában 
Érdekes lenne megvizsgálni, hogy a 3., 5. és 7. rétegek poliédereinek az alakja hogyan változik a 2., 4., 6. és 8. rétegek ötszöges szimmetriájú poliédereinek az alakja függvényében. De még az sem világos, hogy milyen mérőszámokkal (pl. térfogat, beírt gömb sugara, köré írt gömb sugara, szimmetriatengelyek hossza valamelyikével, vagy más mennyiségekkel) lenne érdemes jellemezni a poliédercellák alakját, hogy ilyen összefüggéseket kapjunk.

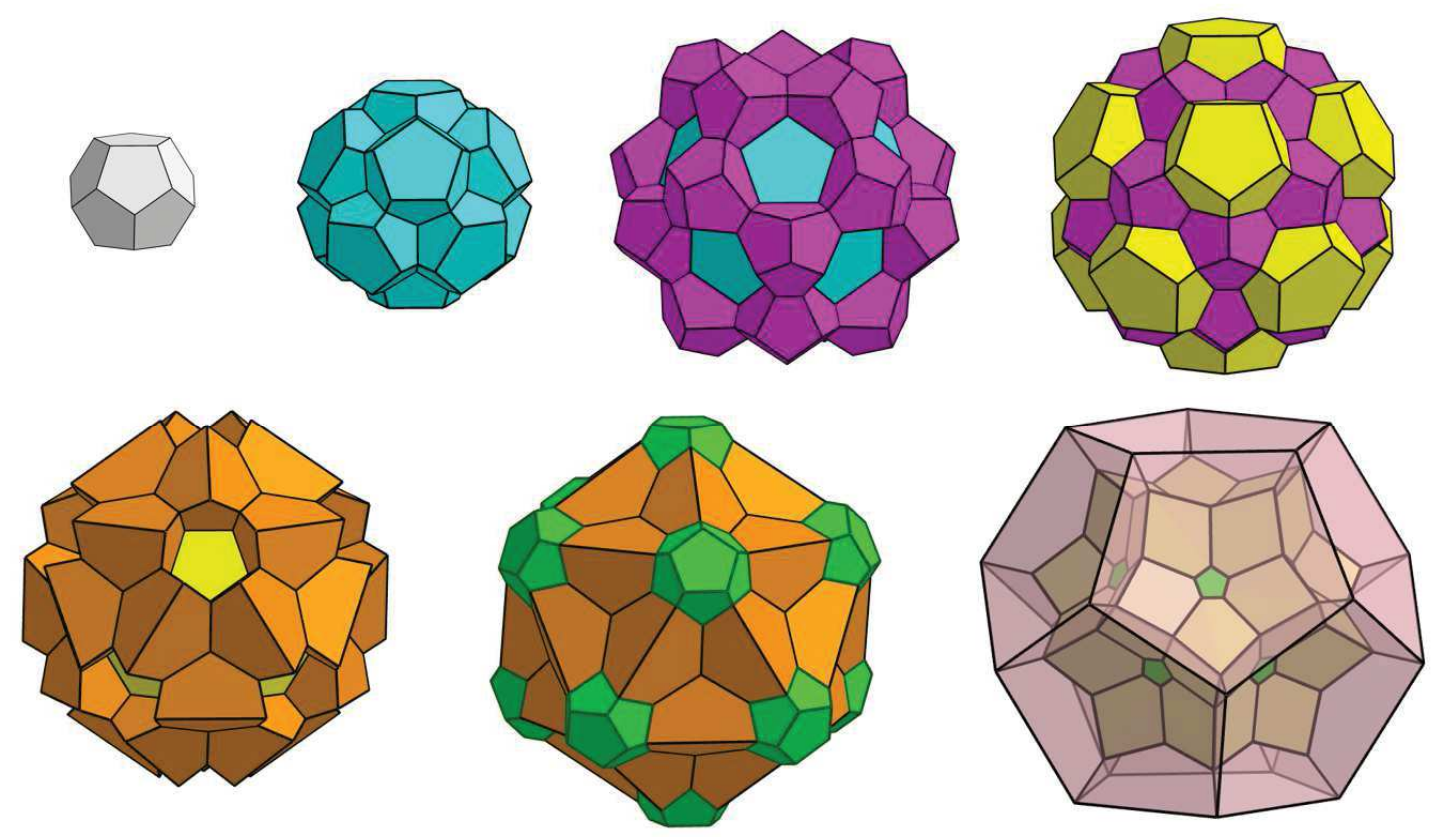

2. ábra. A 120-cella dodekaéderes szimmetriájú 3D reprezentációjának felépítése az egyes rétegek indexeik szerinti növekvő sorrendben történő hozzáadása után

\section{A 600-cella élgráfjának a 3D reprezentációi}

Ebben a fejezetben a 600-cella élgráfjának két 3D reprezentációját is megadjuk.

Mivel a 600-cella a 120-cella duálisa, ezért a 600-cella absztrakt élgráfja megkapható egy olyan gráfként, melynek csúcsai a 120-cella celláinak felelnek meg, két csúcs pedig akkor van összekötve éllel, ha a 120-cellában a nekik megfeleltetett celláiknak közös 2D lapjuk van. A 600-cella absztrakt laphálójának a további elemei, a 2D lapoknak és celláknak megfelelő laphálóelemek pedig azon csúcshármasok, ill. csúcsnégyesek, melyek eseteiben bármely két csúcs éllel van összekötve az élgráfban.

Ha a 120-cella szabályos dodekaéder hiperlapjainak középpontjait gömbközéppontoknak vesszük a 4-dimenziós euklideszi térben, olyan maximális gömbsugarakat használva, hogy gömbpakolást kapjunk, akkor a 120 gömb mindegyikének 12 szomszédja lesz (azaz 12 másik gömb érint egy gömböt a maradék 119 gömbböl) a 4-dimenziós euklideszi térben (két gömb pontosan akkor lesz érintő, ha a gömbközéppontok celláinak van egy közös 2-dimenziós lapja, az érintési pontok a cellaközéppontok által meghatározott 600-cella élfelező pontjaiban lesznek).

Ekkor a gömbök érintési pontjai egy $F$ gömbfelületen helyezkednek el, és azt a 120 gömb mindegyike merőlegesen metszi. Alkalmazzunk egy olyan inverziót, melynek a középpontja az egyik gömb középpontjának az $F$ gömbfelület középpontából az $F$ gömbfelületre történő vetítéssel kapható meg! Ekkor 120 olyan gömböt kapunk, melyek középpontjai egy hipersíkon fekszenek, mellyel lemetszve a gömböket, egy 3D gömbelrendezést kapunk 
dodekaéderes szimmetriával. Ebben minden gömbnek 12 szomszédja van, egy gömb tartalmazza az összes többit, a maradék 119 gömb pedig gömbpakolást alkot - az egymást érintő gömbök érintési síkjai cellarendszert határoznak meg, a cellarendszer dodekaéderes szimmetriával rendelkezik. Mind a 119 korlátos cella beírt gömbje a gömbpakolás eleme.
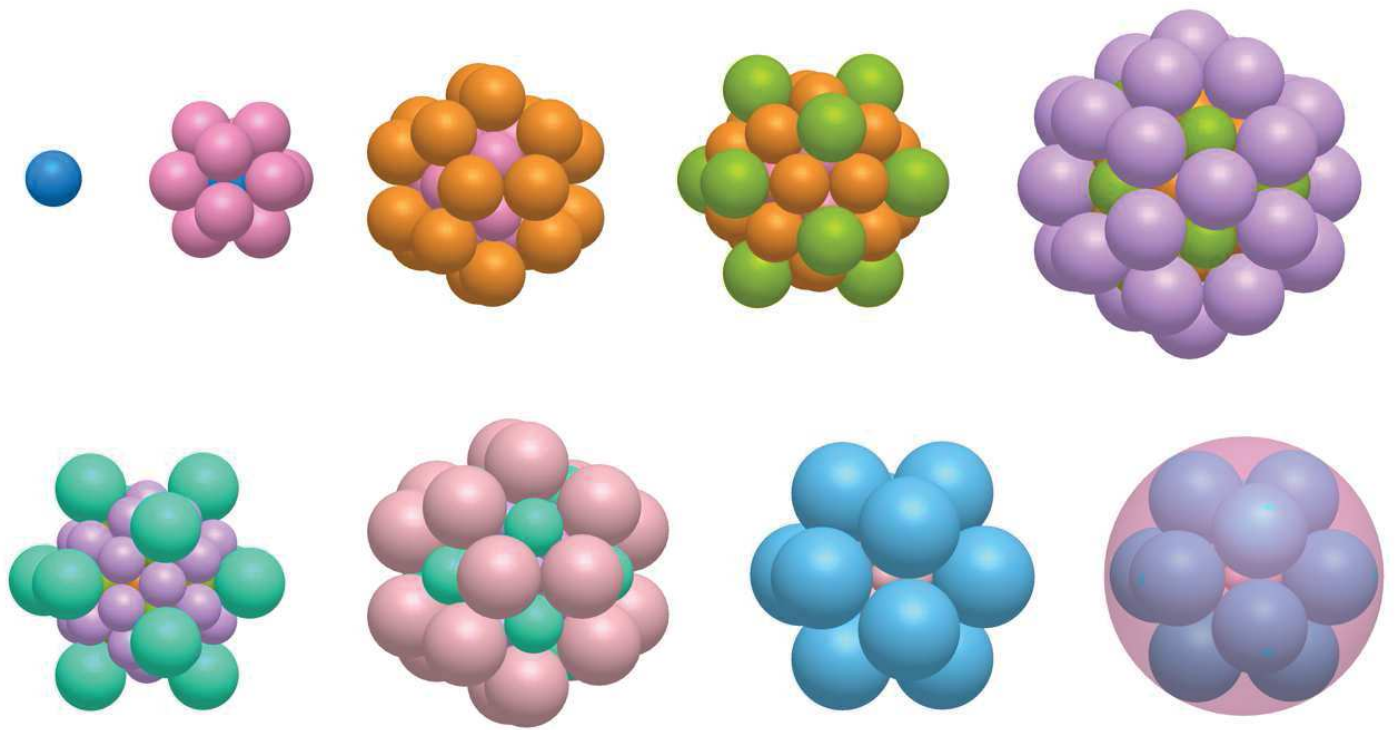

3. ábra. A 600-cella dodekaéderes szimmetriájú 3D gömbelhelyezésként történő reprezentációjának felépítése az egyes rétegek indexeik szerinti növekvő sorrendben történő hozzáadása után

Ezért a 120 darab 3D gömb 9 különböző sugarú gömbböl áll, az egyforma sugarú gömbök egy-egy rétegben helyezkednek el, 9 rétegre osztva fel a gömbelhelyezést (ld. 3. és 4. ábra). Ez a gömbelhelyezés a 600-cella élgráfjával ekvivalens: a gömböknek feleltehetők meg a 600-cella csúcsai, az éleknek pedig a gömbök páronkénti érintési pontjai (amelyek két-két gömbre illeszkednek).

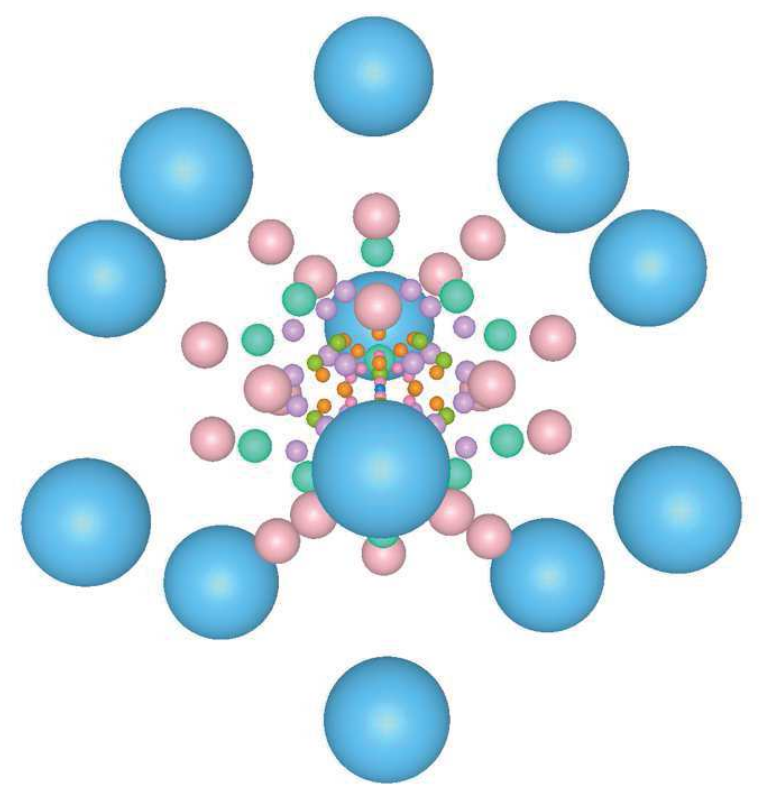

4 ábra. Azonos arányban lekicsinyített gömbök a 600-cella dodekaéderes szimmetriájú 3D gömbelhelyezésként történő reprezentációjából 
Az általunk készített modellben közvetlenül a 600-cella csúcsainak a 4-dimenziós koordinátáiból számítottuk ki a 3D gömbök középpontjait és sugarait, inverziót és merőleges vetítést alkalmazva - ugyanis így egyszerübb elkészíteni a gömböket, mint közvetlenül a 3D gömbkonfiguráció érintési tulajdonságai alapján rétegenként megszerkeszteni a gömböket (mivel ilyenkor több réteg gömbjeinél is szükséges 3D inverzió alkalmazása a szerkesztésekhez).

A következőkben a 600-cella élgráfjának egyetlen ábrában történö, átlátható vizualizációját adjuk meg. Ehhez érdemes a 120-cella dodekaéderes szimmetriájú 3D reprezentációjának a duálisát elkészíteni: a 600-cella élgráfjának a 3D reprezentációjában a 600-cella csúcsaihoz 3-dimenziós térbeli csúcsok tartozzanak, és a csúcshalmaz dodekaéderes szimmetriájú legyen. Ekkor a gráf csúcsai ikozaéderek, dodekaéderek, és egy ikozidodekaéder csúcsaiban helyezkednek el (kivéve az 1. és 9. osztály egyelemü halmazait). A csúcsokat 9 osztályba sorolhatjuk (ld. [2], [4]): az 1. osztály egypontú - a dodekaéderes szimmetria középpontja, a 2., 4., 6. és 8. osztály csúcsainak a konvex burka ikozaéder, a 3. és 7. osztály csúcsainak konvex burka dodekaéder, az 5. osztály csúcsainak konvex burka ikozidodekaéder, a 9. osztály egyelemü, ez a végtelen távoli pont (a 3-dimenziós euklideszi teret jelen esetben egy végtelen távoli ponttal kibővített, ezáltal kompaktifikált euklideszi térnek kell tekintenünk - a dodekaéderes szimmetria következtében a 600-cellának a szimmetriaközépponthoz tartozó csúcsával átellenes csúcsát a 3D térben már nem tudjuk reprezentálni).

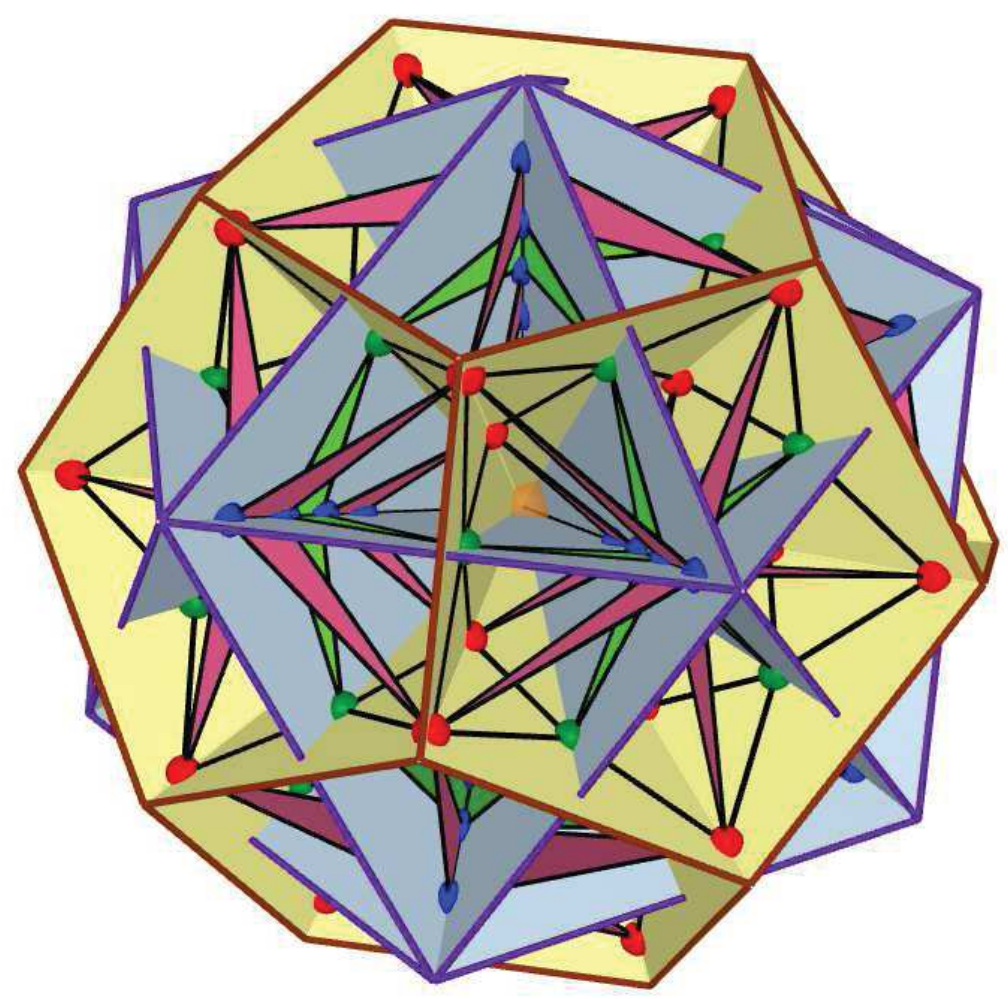

5. ábra. A 600-cella élgráfjának 3D reprezentációja takaró lapokkal

Az egyes csúcsok iránya a szimmetria egy fixen hagyott dodekaédere által meghatározott lapközéppontok, csúcsok, ill. élfelezőpontok irányába kell, hogy essen, így hasonlóság erejéig összesen 6 szabadsági foka van a 3D reprezentáció csúcshalmazának (mivel ekkor a csúcsok 1. és 2. osztályának halmaza adottnak tekinthető). 
Megfelelő 2D síkidomok berajzolásával (a szimmetriaközéppontból dodekaéder-élekig, ill. ikozaéder-élekig terjedő sárga, valamint világoskék háromszöglapokkal) segítjük a vizualizációt: a létrejövő takarások miatt nem lesz kusza az ábrázolás, és a szimmetriák hangsúlyozása is megtörténik ezáltal. Ezek a háromszöglapok tehát nem a 600-cella lapjai, az oldalaik sem a 600-cella élei.

A 600-cella 2D lapjainak összességét nem ábrázoljuk, csak megjegyezzük, hogy pontosan a háromszögekhez (azaz azon csúcshármasokhoz, melyekben bármely két csúcs között van él) tartozik 2D lap, valamint, hogy azon csúcsnégyesekhez, melyekben bármely két csúcs között van él, 3D cellák tartoznak.

A 600-cellának az 5. ábrán látható 3D reprezentációjában a narancssárga csúcs az 1. osztály csúcsa (a szimmetriaközéppont), a kék csúcsok a 2., 4., 6. és 8. osztály csúcsai (a szimmetriaközéppontból kifelé növekvő indexszel), a vörös csúcsok a 3. és 7. osztály csúcsai (szintén kifelé növekvő indexszel), a zöld csúcsok pedig az 5. osztály csúcsai (a 9. osztály csúcsa a végtelen távoli pont, nincs ábrázolva). Az egyes osztályok csúcsai egyforma távolságra vannak a szimmetriaközépponttól.

Az egyes osztályokon belüli élek a konvex burok élei, azaz a kék legközelebbi és legtávolabbi csúcsok (2. és 8. réteg csúcsai) esetén ikozaéder-élek, a vörös csúcsok esetén dodekaéder-élek, és a zöld csúcsok esetén ikozidodekaéder-élek tartoznak az élgráfhoz. Ezen élek nincsenek megjelenítve az 5. ábrán (hogy az ábra ne legyen átláthatatlan), de a világoskék, és sárga takarólapok tartalmazzák a dodekaéder-éleket, ill. az ikozaédér-éleket, és ezeknek a lapoknak a lila, ill. barna külső élei épp ilyen élhálózatokat adnak ki, csak a szimmetriaközéppontból kinagyítottan (de az ikozidodekaéder-élekre ez nem mondható el).

A szimmetriaközéppontból kiinduló, sugárirányban elhelyezkedő egymás utáni kék csúcsok élekkel vannak összekötve (ezek szerepelnek az ábrán), sőt a legbelső kék csúcsokat élek kötik össze a szimmetriaközéppontbeli csúccsal. A sárga háromszöglapokon élek kötik össze a zöld csúcsot 4 vörös csúccsal (ez szerepel az ábrán). Két egymás utáni kék csúcsot a szimmetriaközépponttól való távolságra nézve közöttük elhelyezkedő, hozzájuk legközelebbi sárga lapokon található csúcsokkal élek kötik össze, azaz a 2. és 4. osztály kék csúcsai és a 3. osztály vörös csúcsai, a 4. és 6 . osztály kék csúcsai és az 5. osztály zöld csúcsai, valamint a 6. és 8. osztály kék csúcsai és a 7. osztály vörös csúcsai élekkel vannak összekötve ezekben az esetekben, ezeket az éleket vörös, ill. zöld háromszöglapok éleikén ábrázoltuk (ezek a 2D lapok különben ténylegesen a 600-cella 2D lapjai). Ami még hiányzik az ábráról: a 9. osztály végtelen távoli pontban levő csúcsát él köti össze a 8. osztály minden csúcsával.

\section{Oktatási tapasztalat}

A SZIE Ybl Miklós Építéstudományi Karon oktatott „Számítógépes térgeometriai modellezés" kurzus egyik témaköre a poliéderek modellezése. A tapasztalatok alapján a hallgatóknak megfelelő ismereteik vannak az alaptestekről (hasáb, gúla) és a szabályos testekről. De további konvex és nem konvex poliéderekről, vagy azok tulajdonságairól az ismereteik elég hiányosak. A konvex poliéderek dualitását csak szabályos poliéderek esetében értik jól, már az archimédeszi poliéderek esetében is nehézséget okoz számukra a duális poliéder konstrukciójának a megértése.

A 120-cella 3D reprezentációja olyan feladatnak bizonyult, mely elég nagy kihívás volt a hallgatóknak, de a térbeli szerkesztési lépésekre bontott feladat már megoldható volt számukra. A 600-cella élgráfjának 3D reprezentációját a 12-szomszédos gömbpakolással a hallgatók nagyon élvezték és látványosnak találták, itt az egyszerűség kedvéért a gömbközéppontok koordinátáit egy szöveges fájlban megkapták (a koordináták GeoGebrával 
lettek kiszámítva) és AutoCAD script fájlt készítettek, melynek futtatásakor készült el a gömbpakolás.

A kurzuson a 3D poliéderek modellezéséhez Cabri 3D, GeoGebra, és AutoCAD szoftvereket használunk. Geometriai módszerekkel szerkesztjük a poliédereket. A 120-cella modellezéséhez a Cabri 3D szoftvert használták legszívesebben a hallgatók, de volt, aki AutoCAD-ben szívesebben modellezte a cellákat, korábbi AutoCAD-es modellezési tapasztalatai miatt. A GeoGebrát túlságosan matematikai szintaktikát használónak találták ennek a feladatnak a megoldásához, így kissé nehézkesen tudták alkalmazni, de mivel megfelelő elökészületek után a GeoGebrában a Sorozat paranccsal nagyon látványosan megsokszorozhatók a cellák, ezért a 120-cella GeoGebrában történő modellezése is nagyon érdekelte a hallgatókat.

A cellák elkészítéséhez felhasználtuk a szimmetriákat és az alkalmazható geometriai transzformációkat. Mindez hozzásegítette a hallgatókat, hogy jobban megértsék a poliéderek kombinatorikus és metrikus tulajdonságait, és fejlődjön a térlátásuk.

\section{Köszönetnyilvánítás}

Szeretném megköszönni Németh Lászlónak, hogy erről a témakörről előadhattam Sopronban a Matematika Oktatása és Kutatása Szeminárium (MOKUS) 2018-as programjában.

\section{Irodalomjegyzék}

[1] 120-cell, Wikipedia, http://en.wikipedia.org/wiki/120-cell

[2] 600-cell, Wikipedia, http://en.wikipedia.org/wiki/600-cell

[3] The 120-Cell, Eusebeia, http://eusebeia.dyndns.org/4d/120-cell

[4] The 600-Cell, Eusebeia, http://eusebeia.dyndns.org/4d/600-cell 